\title{
Effect of drying on antioxidant capacity, physicochemical and functional characteristics of Mexican serviceberry fruit
}

\author{
Adan Melgar-Almanza ${ }^{a}$, Salvador Horacio Guzmán-Maldonado ${ }^{\mathrm{b}, *}$, Carlos Núñez-Colín ${ }^{\mathrm{c}}$, \\ Maria Guadalupe Herrera-Hernández ${ }^{\mathrm{b}}$ and Gabriela Medina-Ramos ${ }^{\mathrm{a}}$ \\ ${ }^{a}$ Universidad Politécnica de Guanajuato, Cortazar, Guanajuato, México \\ ${ }^{\mathrm{b}}$ Laboratorio de Alimentos, Campo Experimental Bají (INIFAP), Celaya, Gto., México \\ ${ }^{\mathrm{c}}$ Universidad de Guanajuato, Campus Celaya-Salvatierra, Celaya, Gto., México
}

Submitted 24 February 2015; accepted 25 March 2015

\begin{abstract}
.
BACKGROUND: There are five species of Malacomeles (family Rosaceae) endemic in America. They grow from southern Texas to north Honduras. Of those five species, M. denticulata (Mexican serviceberry) is the most widely distributed in Mexico. OBJECTIVE: To increase knowledge of how drying method affect physical and chemical characteristics of Mexican serviceberry fruit.

METHODS: Fruit was dried through the process of sun-, shade- or hot air. Vitamin C, total phenols, condensed tannins, anthocyanins, simple phenols, Trolox equivalent (TEAC) and oxygen radical antioxidant (ORAC) capacities were determined in serviceberry raisins.

RESULTS: Titratable acidity, Brix, calcium, iron, and condensed tannins were higher in shade-dried raisins. The total phenolics ranged from 389.2 to $434.2 \mathrm{mg}$ eq. gallic acid/100 g and were in the range reported for grape raisins. Total fiber was up to 4 -fold higher in serviceberry raisins compared to those of grape raisins. Calcium and iron contents were on average 4.3- and 55-fold higher, respectively, compared with that reported for grape raisins. -Shade-dried, sun-dried and hot air-dried serviceberry raisins showed by far, higher Trolox equivalent compared to oxygen radical antioxidant capacity.

CONCLUSION: Shade drying process is economic and advantageous. It helps to extend the Mexican's serviceberry fruit shell, preserving the fruit's outstanding functional characteristics.
\end{abstract}

Keywords: Malacomeles denticulata, Mexican serviceberry, raisins, nutritional, phenolics, antioxidant capacity

\section{Introduction}

Five species of Malacomeles that belongs to the family Rosaceae, have been described previously; they are distributed throughout the United States (Texas), Mexico, Guatemala, Costa Rica and Honduras. Of those five species, M. denticulata (Knut, G.N. Jones) was the most widely distributed in Mexico [1]. The fruit of M. denticulata is known as southern false serviceberry and Mexican serviceberry. The production areas of Mexican serviceberry have been identified and the production potential is promising. Additionally, the interest in serviceberry increased due to its tolerance to several environmental conditions such as frost, drought, clay soil conditions and poor drainage.

\footnotetext{
*Corresponding author: Salvador Horacio Guzmán-Maldonado, Laboratorio de Alimentos - Campo Experimental Bajío (INIFAP). Km. 6.5 Carretera Celaya-San Miguel de Allende, C. P. 38110, Celaya, Gto., México. Tel.: +52 461611 5323; Fax: +52 461; E-mail: shoraciogm@gmail.com.
} 
The fruit of Mexican serviceberry is similar in size and shape to that of Saskatoon berry (Amalenchier alnifolia) (Nutt.) except for color and number of seeds. Mexican serviceberry fruit is pink in color and shows 1 to 3 little seeds [2] in contrast to the dark purple color of fruit and 5 to 10 seeds of the Saskatoon berry. Mexican Serviceberry shows an advantage compared to other Rosaceae fruits; because of its thinner skin it is easy to dry. We recently demonstrated that Mexican serviceberry shows high contents of fiber, calcium, vitamin $\mathrm{C}$, total soluble phenols and condensed tannins [2]. In addition, these species showed higher Trolox equivalent antioxidant (TEAC) and oxygen radical antioxidant (ORAC) activities compared to those of fruit commonly consumed.

Raisins have been a popular food for many centuries. Raisins are obtained by dehydrating grapes, usually through sun exposure or drying tunnels [3]. The production of grape raisins through shade has been also explored [4]. Drying methods are known to have a significant impact on the sensorial, nutritional and functional characteristics [5]. The aim of this work was to evaluate the effect of drying processes of Mexican serviceberry fruit on physical and nutritional characteristics. We also evaluated the functional quality of raisins via analysis and quantification of phenolic compounds and antioxidant capacities of raisin extracts.

\section{Materials and methods}

\subsection{Plant material}

Mexican serviceberry fruit was harvested from shrubs grown in agricultural lands of Celaya, Guanajuato, Mexico. Ripe fruit were harvested in June 2013 from different shrubs from the site. Immediately after harvest, samples were protected from light to avoid loss of antioxidant components. When the samples $(n=6)$ arrived at the laboratory, they were divided in two portions. One portion was used to determine the physicochemical parameters of fresh fruit on the same day of harvest. The other portion was subjected immediately to one of the three different drying processes: sun exposure, in the shade and hot air. For sun-drying process, Mexican serviceberry fruit was dried out doors under the sun in plastic trays. For shade-drying process, raisins were dried in our laboratory $\left(27 \pm 2^{\circ} \mathrm{C}\right)$ in plastic trays. For hot air-drying process, fruit was placed in a hot air dryer $\left(65 \pm 1^{\circ} \mathrm{C}\right)$ (Riosa, H-41, México, D. F.). The drying processes ended when raisins showed moisture content of $14 \pm 2 \%[5,6]$. Raisins were not subjected to any chemical treatment except for immersion in $\mathrm{HCl}(0.1 \mathrm{~N})$ solution for $30 \mathrm{~s}$ followed by washing in distilled water at $25^{\circ} \mathrm{C}$ for $5 \mathrm{~min}$.

\subsection{Physicochemical characterization}

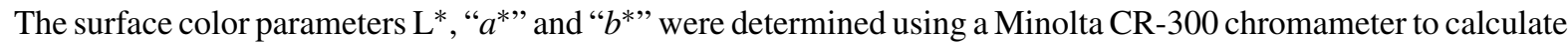
HUE $\left[=\operatorname{arctang}\left(b^{*} / a^{*}\right)\right]$ and chroma $\left[=\left(a^{* 2}+b^{* 2}\right)^{1 / 2}\right]$. The pH was measured with a pHmeter (MI 255, Hanna Instruments, Woonsocket, RI, USA) and titratable acidity was determined by titration with $0.1 \mathrm{M} \mathrm{NaOH}$ [7]. Total soluble solids ( ${ }^{\circ}$ Brix) were determined using fruit juice with a hand refractometer (Pal-1, ATAGO, Tokyo, Japan).

\subsection{Nutritional composition}

Nitrogen (ref. 960.52), ether extract (ref. 920.85) and ash (ref. 923.03) were measured by AOAC-approved methods [7]. Dietary fiber was determined by a standardized method [8]. The remaining percentage was considered to represent carbohydrates. The conversion factor for total protein was $6.25(\mathrm{~N} \times 6.25)$. Calcium and iron were determined after $\mathrm{HClO}_{4} / \mathrm{HNO}_{3}$ digestion in an inductively coupled plasma atomic emission spectroscopy analyzer (3000SC, Perkin Elmer, Wellesley, MA, USA).

\subsection{Total soluble phenols}

Each sample was extracted with methanol/water (30:70, v/v) for $10 \mathrm{~min}$ with a shaker (Maxi Mix II M37615, Thermo Scientific, Dubuque, IA, USA), in the dark. The supernatant identified as phenol extract was recovered and the total phenols were determined using Folin-Ciocalteu reagent [9]. Absorbance was measured using a UVVis spectrophotometer (Jenway 6405, Staffordshire, UK) at $760 \mathrm{~nm}$. Total soluble phenols were calculated using a standard curve of gallic acid and were expressed as $\mathrm{g}$ of gallic acid equivalent per $100 \mathrm{~g}$, fresh weight (FW). 


\subsection{Condensed tannins}

Fruit samples were extracted with methanol in capped, rotating test tubes for $20 \mathrm{~min}$. The supernatant was recovered and condensed tannins (CT) were measured spectrophotometrically at $500 \mathrm{~nm}$ (Jenway $6405 \mathrm{UV}-$ Vis, Staffordshire, UK) [10]. CT values were reported as $\mathrm{g}(+)$ catechin Eq/100 g, FW after comparing with a (+) catechin standard curve.

\subsection{Total anthocyanins}

Fruit samples were extracted with acidified ethanol (ethanol/HCl, $1 \mathrm{~N}, 85: 15, \mathrm{pH} 1.0$ ) for $45 \mathrm{~min}$. The supernatant was added to acidified ethanol up to $50 \mathrm{~mL}$. Absorbance (Jenway $6405 \mathrm{UV}$-Vis, Staffordshire, UK) was recorded at $535 \mathrm{~nm}$. Total anthocyanins (TAN) content was calculated and reported as grams cyanidin 3-glucoside equivalents, $\mathrm{FW}$, as follows [11]:

$T A N=(A / \varepsilon)(V / 1000)(M W)(1 / S W)(106)$

Where: $A=$ sample absorbance; $\varepsilon=$ molar absorptivity of the cyanidin-3-glicoside $\left(\mathrm{cm}^{-1} \cdot \mathrm{M}^{-1}\right) ; V=$ total volume of anthocyanin extract; $M W=$ molecular weight of cyanidin-3-glucoside (449 Da); $S W=$ sample weight.

\subsection{Simple phenols}

The phenol extracts recovered for the analysis of total soluble phenols were utilized to determine phenolic acids, flavanols and flavonols by HPLC. A $15 \mathrm{~cm} \times 4.6 \mathrm{~mm}$ internal diameter, 5- $\mu \mathrm{m}$ particle size Zorbax octadecylsilane (ODS-C18) (ABC Instrumentación, Distrito Federal, México) reversed-phase column was used. Linear gradient elution was carried out using solvent A (acetic acid/water, 2:98, v/v), and solvent B (acetic acid/acetonitrile/water, 2:30:68, v/v/v). During the analysis, the solvent gradient was programmed from $10 \%$ to $100 \% \mathrm{~B}$ in $\mathrm{A}$, in $30 \mathrm{~min}$, with a flow rate of $1.5 \mathrm{~mL} \cdot \mathrm{min}^{-1}$ [12]. The identification and quantification of the peaks were carried out from (1) the retention times, (2) the spectra derived from the DAD in comparison with those from authentic standards, and (3) by spiking with standards of the suspected compounds. Gallic, protocatechuic, 4-hydroxybenzoic, vanillic, chlorogenic, caffeic, syringic, coumaric, ferulic, benzoic and salicylic acids, as well as (+)-catechin, vanillin, epicatechin (EC) and epigallocatechin gallate (EGCg) were detected at $280 \mathrm{~nm}$; meanwhile, ellagic acid, quercetin and rutin were detected at $360 \mathrm{~nm}$. Simple phenols were reported as mg per $100 \mathrm{~g}, \mathrm{FW}$.

\subsection{Antioxidant capacities}

The ABTS $(7 \mathrm{mM})$ radical cation (ABTS+) solution was produced by reacting ABTS with $2.45 \mathrm{mM}$ potassium persulfate and allowing the mixture to stand in the dark at room temperature for $12-16 \mathrm{~h}$ before use. The ABTS+ radical was diluted with potassium phosphate-buffered saline to give an absorbance of about $0.700 \pm 0.020$ at $734 \mathrm{~nm}$. To measure antioxidant capacity, $10 \mu \mathrm{L}$ of sample was mixed with $990 \mu \mathrm{L}$ of radical solution. Absorbance was monitored at $734 \mathrm{~nm}$ for $6 \mathrm{~min}$. The decrease in absorption at $734 \mathrm{~nm}, 6 \mathrm{~min}$ after addition of the sample, was used for calculating the TEAC value comparing with a standard curve of TROLOX [13]. Results were expressed in terms of mmol Trolox Eq/100 g of sample, FW. The oxygen radical absorbance capacity assay (ORAC) of samples was also carried out [14]. The assay measures the ability of antioxidant compounds in test materials to inhibit the decline of fluorescein fluorescence that is induced by a peroxyl radical generator, AAPH. The final results (ORAC values) were calculated using the differences between blank and sample areas under the quenching curves of fluorescein, and were expressed as mmol Trolox equivalent per $100 \mathrm{~g}$, FW.

\subsection{Statistical analysis}

All data were reported as means \pm standard deviations $(n=6)$. Statistical analysis was performed using the JMP.5.0.1 software (a business unit of SAS, 1989-2003 SAS Institute Inc., NC, USA). Differences among means were tested for significance by ANOVA procedures and Tukey's test, using a level of significance of 0.05. 


\section{Results and discussion}

\subsection{Physicochemical characteristics}

Differences in the time needed for Mexican serviceberry fresh fruit to dry were observed among treatments. It takes around $14 \mathrm{~h}$ of sun exposure and $12 \mathrm{~h}$ in the hot air drier to reach the desirable moisture $(14 \%)[5,6]$; meanwhile, it takes around $120 \mathrm{~h}(5 \mathrm{~d})$ for the shade-drying process to produce Mexican serviceberry raisins (data not shown). The time needed for shade-drying process was shorter than the 4-6 weeks needed to produce grape raisins through the same process [15] or the $7-30 \mathrm{~d}$ needed to produce grape raisins through sun-drying process [16]. Differences in drying time between grape and Mexican serviceberry are due to the skin thickness and fruit size variation. Grape skin is a natural barrier to water loss; meanwhile Mexican serviceberry fruit has a thin which facilitates the loss of moisture. Also, grape fruit sizes 1-1.5 cm diameter while Mexican serviceberry is up to $1.2 \mathrm{~mm}$ in diameter [2].

Values of some physicochemical characteristics of fresh fruit in this work were similar to those reported by Cazares-Franco et al. [2]. Evidently, the lightness $\left(L^{*}\right)$ of color affects the appearance of raisins. The $L^{*}$ values in the fresh fruit and raisins are shown in Table 1; raisins showed higher $L^{*}$ values, in other words, they were darker than fresh fruit. In fact, sun-dried raisins were noticeable darker than shade-dried and hot air-dried raisins. On the other hand, the perceptible and overall color impression of the raisins depends on the relative amount of red and yellow color, which is expressed as an angle of hue in the CIELAB color space system. Hue angles are defined in color as $0 / 360^{\circ}$ for red/magenta, $90^{\circ}$ for yellow, $180^{\circ}$ for green, and $270^{\circ}$ for blue [17]. The lower hue value of fresh fruit compared to hue values of raisins mirrored the red-pink color showed by ripe Mexican serviceberry [2]. The hue values of sun-dried raisins denotes a more yellow tint development during process and were similar to those reported for grape raisins (51.1) [18]. Shade- and hot air-dried raisins showed lower hue value compared to sun-dried raisins; this mirrored the attractive red color of the product. The metric chroma $\left(C^{*}\right)$ correlates for the saturation of color [17]. Chroma of the fresh fruit was higher indicating a more vivid color in contrast to the lower $C^{*}$ vale of sun-dried raisins. Shade- and hot air-dried raisins decreased 33 and $44 \%$, respectively, the $C^{*}$ value of fresh fruit signifying loses in the saturation of color.

The $\mathrm{pH}$ of raisins was lower than the $\mathrm{pH}$ of fresh fruit but similar compared with $\mathrm{pH}$ of grape raisins (3.41-3.96) [19]. Also, raisins showed lower values of titratable acidity compared to that of fresh fruit (Table 1) and were similar to those reported by AlAskari et al. [20] for different commercial raisins (2-3.5 g/100 g, FW). Acidity is sometimes promoted as a good predictor of raisin grades. Grape acids, which is mostly tartaric and a lesser extent malic, are responsible for raisins quality. There is no information for the composition of organic acids for Mexican serviceberry; in consequence it is not possible to indicate which organic acids contribute to acidity of raisins, although like Rosaceae the most abundant is malic acid. On the other hand, as a general rule, grapes should have average soluble solids readings of at least $10^{\circ}$ Brix in order meet minimum incoming grade standards [21]; Mexican serviceberry fresh fruit showed $15.7^{\circ}$ Brix which make this fruit a good candidate for the production of a good quality raisins. The ${ }^{\circ}$ Brix contributes to raise weight as well as the raisins' physical characteristics (meatiness and wrinkling) [22].

\subsection{Chemical composition and mineral contents}

Raisin provides essential nutrients and health related bioactive components. Table 2 shows the chemical composition of Mexican serviceberry raisins. Tukey's test shows that no significant $(p<0.05)$ difference exists on protein and

Table 1

Physicochemical characteristics of fresh fruit and raisins of Mexican serviceberries

\begin{tabular}{|c|c|c|c|c|c|c|}
\hline Process & $\mathrm{L}^{*}$ & Hue (h) & Chroma $\left(\mathrm{C}^{*}\right)$ & $\mathrm{PH}$ & $\begin{array}{l}\text { Titratable acidity } \\
\left(\mathrm{g} \text { MAE } 100^{-1} \mathrm{~g}\right)\end{array}$ & TSS ( ${ }^{\circ}$ Brix $)$ \\
\hline Fresh fruit & $45.6 \pm 0.21 \mathrm{a}$ & $20.2 \pm 0.39 c$ & $28.1 \pm 0.10 \mathrm{a}$ & $5.1 \pm 0.10 \mathrm{a}$ & $5.1 \pm 0.01 \mathrm{a}$ & $15.7 \pm 0.14 \mathrm{c}$ \\
\hline Sun-dried & $14.6 \pm 1.68 \mathrm{~d}$ & $56.7 \pm 0.66 \mathrm{a}$ & $11.7 \pm 0.80 \mathrm{~d}$ & $3.9 \pm 0.30 \mathrm{c}$ & $2.1 \pm 0.03 \mathrm{c}$ & $5.93 \pm 0.12 \mathrm{a}$ \\
\hline Shade-dried & $22.9 \pm 0.25 \mathrm{c}$ & $39.2 \pm 3.02 \mathrm{~b}$ & $18.8 \pm 0.31 b$ & $3.5 \pm 0.21 b$ & $2.3 \pm 0.05 \mathrm{~b}$ & $5.87 \pm 0.10 \mathrm{a}$ \\
\hline Hot air-dried & $24.6 \pm 0.31 \mathrm{~b}$ & $40.4 \pm 0.73 b$ & $15.9 \pm 0.33 c$ & $3.6 \pm 0.36 \mathrm{c}$ & $2.0 \pm 0.16 \mathrm{c}$ & $5.03 \pm 0.06 \mathrm{~b}$ \\
\hline
\end{tabular}

Means in the same column with a common letter are not significantly different $(p<0.05$, Tukey's test). MAE = Malic Acid Equivalent. 
Table 2

Chemical composition (\% FW) and mineral content (mg $\left.100^{-1} \mathrm{~g} \mathrm{FW}\right)$ of fresh fruit and raisins of Mexican serviceberries

\begin{tabular}{|c|c|c|c|c|c|c|c|c|}
\hline \multirow[t]{2}{*}{ Process } & \multirow[t]{2}{*}{ Protein } & \multicolumn{2}{|c|}{ Fiber } & \multirow[t]{2}{*}{ Ether extract } & \multirow[t]{2}{*}{ Ash } & \multirow[t]{2}{*}{$\mathrm{CH}$} & \multicolumn{2}{|c|}{ Minerals } \\
\hline & & Soluble & Insoluble & & & & Calcium & Iron \\
\hline Fresh fruit & $1.19 \pm 0.10 \mathrm{~b}$ & $0.41 \pm 0.21 \mathrm{~b}$ & $4.17 \pm 0.56 \mathrm{c}$ & $1.51 \pm 0.12 \mathrm{c}$ & $0.79 \pm 0.07 \mathrm{~b}$ & $17.31 \mathrm{c}$ & $241 \pm 11 b$ & $4.5 \pm 0.03 \mathrm{a}$ \\
\hline Sun-dried & $2.13 \pm 0.22 \mathrm{a}$ & $1.95 \pm 0.10 \mathrm{a}$ & $15.77 \pm 0.70 \mathrm{a}$ & $4.56 \pm 0.11 b$ & $1.65 \pm 0.05 \mathrm{a}$ & $45.59 \mathrm{~b}$ & $311 \pm 20 \mathrm{a}$ & $3.3 \pm 0.02 \mathrm{~b}$ \\
\hline Shade-dried & $1.97 \pm 0.38 \mathrm{a}$ & $2.03 \pm 0.14 \mathrm{a}$ & $16.27 \pm 0.45 \mathrm{a}$ & $5.04 \pm 0.19 \mathrm{a}$ & $1.75 \pm 0.10 \mathrm{a}$ & $46.91 \mathrm{a}$ & $331 \pm 35 \mathrm{a}$ & $4.1 \pm 0.04 \mathrm{a}$ \\
\hline Hot air-dried & $1.84 \pm 0.08 \mathrm{a}$ & $1.86 \pm 0.25 \mathrm{a}$ & $14.55 \pm 0.34 \mathrm{~b}$ & $4.51 \pm 0.16 b$ & $1.63 \pm 0.00 \mathrm{a}$ & $45.34 \mathrm{~b}$ & $309 \pm 31 \mathrm{a}$ & $3.1 \pm 0.01 \mathrm{~b}$ \\
\hline
\end{tabular}

Means in the same column with a common letter are not significantly different $(p<0.05$, Tukey's test $)$. $\mathrm{CH}=\mathrm{Carbohydrates}$.

fiber contents between raisins with exception of insoluble fiber of hot air-dried product. Protein content of Mexican serviceberry was similar to those reported by Sabandis et al. [23] and Ghrairi et al. [19] for grape raisins. Soluble fiber accounted for about $13 \%$ of total fiber. This values were slightly higher to those obtained by Camire and Dougherty [24] (1.42-1.76\%) for grape raisins. Interestingly, Camire and Dougherty [24] reported up to 3.85\% insoluble fiber for grape raisins in contrast to $14.55-16.27 \%$ for Mexican serviceberry reported here (Table 2). The beneficial effects of fibers in human health are widely known; dietary fiber, together with other functional phytochemicals, may contribute to the prevention of chronic diseases [25]. According to the American Dietetic Association, a portion of $100 \mathrm{~g}$ of Mexican serviceberry raisins could contribute up to $54 \%$ of the daily recommended intake of fiber ( $30 \mathrm{~g})$. On the other hand, shade-dried raisins have the highest lipids levels (5.04\%), while the lowest lipids content was found sun-dried and hot air-dried raisins, 4.56 and 4.51\%, respectively. Mexican serviceberry showed 2-fold higher content of lipids compared to those reported by Ghrairi et al. [19] for grape raisins. Shade-dried raisins have the highest carbohydrate level $(46.91 \%)$, with no appreciable difference compared to the carbohydrate content found in sun-dried and hot air-dried raisins (Table 2). These results are lower to those obtained by Ghrairi et al. [19], Williamson and Carughi [26] and Sabandis et al. [23] for grape raisins (65.9-76.6\%). Carbohydrates existing in raisins are in the form of glucose and fructose, which can easily pass into the blood without digestion. This explains the nutritional importance, especially for babies, children, coeliac disease patients, athletes, and in immediate energy demanding situations. In addition to these positive effects, the lower content of carbohydrates in Mexican serviceberry could be also of interest for diabetic or overweight patients.

Calcium and iron contents reported here for fresh fruit were similar to those reported by Cazares-Franco et al. [2]. On the other hand, shade-dried raisins showed higher contents of calcium and iron compared to those of sun-dried and hot air-dried raisins (Table 2). Calcium and iron contents of Mexican serviceberry raisins were on average 4.3- and 55-fold higher, respectively, compared with those reported by Ghrairi et al. [19] for grape raisins (49.6-95.2 mg/100 g and $0.06-0.34 \mathrm{mg} / 100 \mathrm{~g}$, respectively). Such contrast could be attributed to differences in soil mineral contents such as $\mathrm{Ca}$ and other minerals where Mexican serviceberry grows. No information concerning the soil content of Ca and Fe was available for our study and for Ghrairi et al. [19]. In conclusion, the nutritional characteristics of Mexican serviceberry raisins make this fruit a good source of fiber and Fe. This is important for children in rural regions who live mostly on diets rich in plants found locally (including Mexican serviceberry fruit), putting them at high risk of deficient growth and development. A 100-g portion of Mexican serviceberry raisins could contribute from $20.63 \%$ to $27.3 \%$ of the daily iron requirement $(15 \mathrm{mg})$ [27].

\subsection{Phenolic composition}

The total phenolic (TP) concentration of raisins produced in this study ranged from 389.2 to $434.2 \mathrm{mg}$ EGA/100 g and was in the range reported by Breksa III et al. [28] and Meng et al. [4] for grape raisins. On the other hand, shade-dried raisins had the highest amount of TP, condensed tannins (CT) and total anthocyanins (TA) followed by hot air-dried and sun-dried raisins (Table 3). In contrast to Karadeniz et al. [18] who reported that procyanidins and flavan-3-ols were completely degraded in sun-dried grape raisins, we observed a $25 \%$ reduction on TA, in sundried Mexican serviceberry raisins. We also observe a 6\%, and 53\% reduction on TP, and CT. However, Mexican serviceberry raisins are excellent TP sources compared with commonly consumed fruits. For example, the TP contents 
Table 3

Total soluble phenols, condensed tannins, and total anthocyanins of fresh fruit and raisins of Mexican serviceberry

\begin{tabular}{lccr}
\hline Process & $\begin{array}{c}\text { Total soluble phenols } \\
\left(\mathrm{mg} \mathrm{GAE} 100^{-1} \mathrm{~g} \mathrm{FW}\right)\end{array}$ & $\begin{array}{c}\text { Condensed tannins } \\
\left(\mathrm{mg}(+) \mathrm{CE} 100^{-1} \mathrm{~g} \mathrm{FW}\right)\end{array}$ & $\begin{array}{c}\text { Total anthocyanins } \\
(\mathrm{mg} \mathrm{C} 3 \mathrm{GE} \mathrm{100}\end{array}$ \\
\hline Fresh fruit & $434.2 \pm 28.0 \mathrm{a}$ & $153.6 \pm 9.8 \mathrm{a}$ & $12.6 \pm 1.01 \mathrm{a}$ \\
Sun-dried & $407.4 \pm 16.4 \mathrm{~b}$ & $72.6 \pm 4.5 \mathrm{c}$ & $9.4 \pm 0.70 \mathrm{~b}$ \\
Shade-dried & $475.9 \pm 35.2 \mathrm{a}$ & $173.6 \pm 11.8 \mathrm{a}$ & $14.4 \pm 2.25 \mathrm{a}$ \\
Hot air-dried & $389.2 \pm 11.3 \mathrm{~b}$ & $129.4 \pm 15.9 \mathrm{~b}$ & $13.7 \pm 3.49 \mathrm{a}$ \\
\hline
\end{tabular}

Means in the same column with a common letter are not significantly different $(p<0.05$, Tukey's test $)$ GAE $=$ Gallic acid equivalent. $(+)$ CE $=(+)$ catechin equivalent $\mathrm{C} 3 \mathrm{GE}=$ Cyanidin 3 glucoside equivalent.

Table 4

Phenolic acids, flavonol and flavanols (mg $100^{-1} \mathrm{~g} \mathrm{FW}$ ) of fresh fruit and raisins of Mexican serviceberry

\begin{tabular}{|c|c|c|c|c|c|c|c|}
\hline \multirow[t]{2}{*}{ Process } & \multicolumn{4}{|c|}{ Phenolic acid } & \multirow{2}{*}{$\begin{array}{c}\text { Flavonol } \\
\text { Rutin }\end{array}$} & \multicolumn{2}{|c|}{ Flavanols } \\
\hline & Benzoic & Caffeic & Gallic & Syringic & & Catechin & EGCg \\
\hline Fresh fruit & $5.7 \pm 0.35 \mathrm{a}$ & $39.3 \pm 0.31 \mathrm{c}$ & $27.9 \pm 0.11 \mathrm{a}$ & $18.5 \pm 0.58 \mathrm{a}$ & $5.5 \pm 0.1 \mathrm{a}$ & $1.5 \pm 0.01 \mathrm{a}$ & $3.5 \pm 0.14 \mathrm{c}$ \\
\hline Sun-dried & $4.6 \pm 0.68 b$ & $46.7 \pm 0.66 \mathrm{a}$ & $11.7 \pm 0.80 \mathrm{~d}$ & $9.3 \pm 0.18 \mathrm{~d}$ & $3.9 \pm 0.30 \mathrm{c}$ & $1.1 \pm 0.03 \mathrm{c}$ & $4.9 \pm 0.22 b$ \\
\hline Shade-dried & $2.9 \pm 0.25 \mathrm{c}$ & $39.2 \pm 0.22 \mathrm{c}$ & $13.8 \pm 0.31 \mathrm{c}$ & $10.4 \pm 0.48 \mathrm{c}$ & $4.5 \pm 0.21 b$ & $1.3 \pm 0.05 b$ & $5.8 \pm 0.21 \mathrm{a}$ \\
\hline Hot air-dried & $4.6 \pm 0.31 b$ & $43.4 \pm 0.73 b$ & $15.9 \pm 0.33 b$ & $11.7 \pm 0.15 b$ & $3.6 \pm 0.36 \mathrm{c}$ & $1.0 \pm 0.16 \mathrm{c}$ & $5.0 \pm 0.31 \mathrm{~b}$ \\
\hline
\end{tabular}

Means in the same column with a common letter are not significantly different $(p<0.05$, Tukey's test). EGCg $=$ Epigallocatechin gallate.

reported for strawberry, raspberry, red plum and grape (150-330 mg/100 g, FW) [29] and blueberry (179 mg/100 g, FW) [30] were significantly lower than the TP contents reported here for shade-dried Mexican serviceberry raisins. The contents of CT in shade- and hot air-dried Mexican serviceberry raisin are attractive given the demonstrated relation of those compounds with human health. For example, a high positive correlation between TP and antioxidant capacity has been established [30,31]. Also, CT are reported to be anticarcinogenic and antimutagenic agents, which attribute to the antioxidative property, important in protecting cellular oxidative damage [32]. On the other hand, comparing the TA levels detected in Saskatoon berry $(25.1-179.0 \mathrm{mg} / 100 \mathrm{~g}$, FW) [33, 34] to those of fresh fruit and raisins, Mexican serviceberry is not a good source of anthocyanins.

The HPLC chromatogram of simple phenolics detected in sun-dried sample is shown in Fig. 1. Benzoic, caffeic, gallic and syringic acids were identified together with the flavonol rutin and flavanols catechin and EGCg (Table 4). Of these compounds, caffeic, gallic, and syringic acids were found to be the predominant ones in raisins and fresh fruit. Abundant simple phenols values of fresh fruit were in agreement to those previously reported by Cazares-Franco et al. [2]. On the other hand, drying processes affected in a different fashion the simple phenols content; for example, the caffeic acid content increased in sun-dried and hot air-dried raisins and was similar in shade-dried raisins compared to that of fresh fruit. Meanwhile, gallic and syringic acid contents were reduced when fresh fruit was dried. On the contrary, EGCg increase when fresh fruit was dried, particularly in shade-dried raisins.

In grape raisins, the most abundant phenolic compounds are quercetin and kaempferol [26]; but they also contain caffeic, gallic, syringic acids, ruitn, (+)-catechin and (-)-epicatechin [4, 18, 26, 28]. When comparing simple phenolics from grape raisins with those detected in Mexican serviceberry raisins, gallic and syringic acids are up to 2.3- and 1.7-fold higher, respectively. On the contrary, rutin is 50\% lower in Mexican serviceberry and catechin is by far higher in grape raisins. However, epigallocatechin gallate (EGCg) has not been reported in grape raisins; meanwhile quercetin, kaempferol, epicatechin, and ferulic, salicylic and coumaric acids present in grape raisins were not detected in Mexican serviceberry raisins. Plant and plant products containing flavanols in particular EPGCg are reported to have glucose lowering effects [35] and represses hepatic glucose production [36] in animals. The presence of EPGCg in Mexican serviceberry raisins makes this product a candidate to evaluate such effects in vivo. 

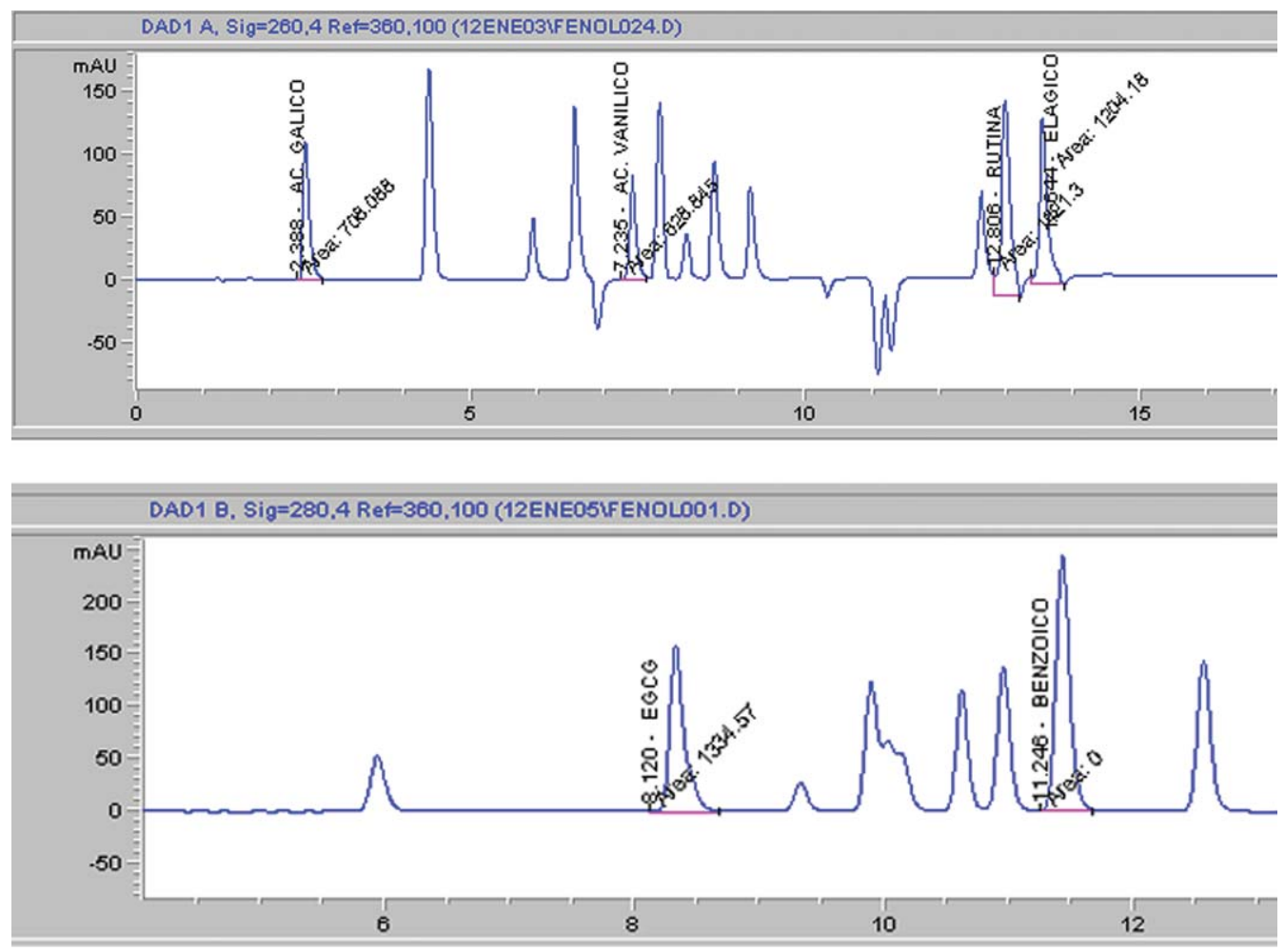

Fig. 1. HPLC chromatograms of A) commercial standards detected at $260 \mathrm{~nm}$ and B) simple phenolics detected at $280 \mathrm{~nm}$ in sun-dried sample.

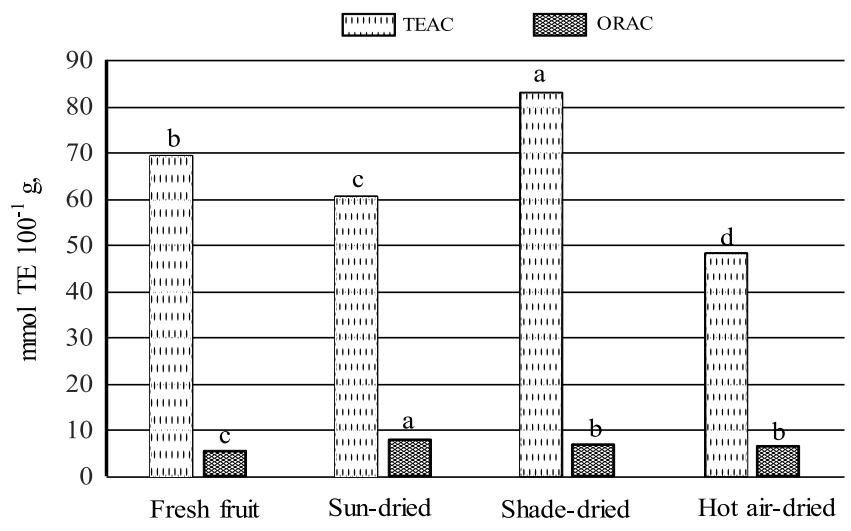

Fig. 2. Trolox equivalent antioxidant capacity (TEAC) and oxygen radical absorbance capacity (ORAC) of Mexican serviceberry. Bars for each antioxidant capacity, with the same letter are not statistically different $(p<0.05$, tukey's test).

\subsection{Antioxidant capacity}

Level of TEAC was higher in shade-dried raisins compared to those of sun- and hot air-dried raisins; meanwhile, levels of ORAC are in general similar among raisins samples (Fig. 2). Levels of TEAC in Mexican serviceberry raisins were by far higher to those reported by Breksa III et al. [28] for grape raisins $(0.77-6.09 \mathrm{mmol} \mathrm{TE} / 100 \mathrm{~g}$, FW). The TEAC value of Mexican serviceberry raisins is by far higher than that of ORAC (Fig. 2). This is not surprising, since flavanols have consistently shown lower antioxidant efficiency in terms of H-donating capacity than flavonols, when 
evaluated in in vitro systems [37]. Not to be underestimated in the TEAC antioxidant activity is the contribution of the TP and phenolic acids; however, little information is available on the contribution of individual phenolic compounds to antioxidant activities in raisins. Levels of TEAC and ORAC detected in Mexican serviceberry fresh fruit were similar to those reported previously [2].

A significant correlation in raisins was observed between TEAC and TP $(r=0.847, p<0.05)$ (data not shown). Significant correlations were also detected between TEAC values and benzoic, caffeic, gallic and syringic acid contents of Mexican serviceberry raisins. Comparing the TEAC values of strawberry $(25.91 \mathrm{mmol} \mathrm{TE} / 100 \mathrm{~g}, \mathrm{FW}$ and raspberry (18.46 mmol TE/100 g, FW) [29] to the TEAC values reported here for raisins (Fig. 2), it is obvious that Mexican serviceberry raisins are by far a better source of antioxidant compounds including grape raisins. On the other hand, ORAC levels showed a lower correlation with TP $(r=0.6752, p<0.05)$ and a significant correlation with benzoic and caffeic levels in raisins.

\subsection{Conclusions}

This is the first report on the physicochemical, nutritional and functional characteristics of Mexican serviceberry raisins. It showed that the shelf life of this perishable fruit could be extended through drying, preserving the outstanding nutrimental and functional properties of the fruit. The results of this work also demonstrate that shade drying process is an inexpensive option to produce Mexican serviceberry raisin with contents of protein, calcium and iron similar or higher to those raisins produced trough sun- or hot air-drying process or those of grape raisins. The outstanding fiber content together with total phenols, condensed tannins, phenolic acid, flavonols and flavanols, makes Mexican serviceberry raisins attractive from a health point of view. The outstanding TEAC antioxidant capacity contributes to the functional quality of raisins. An opportunity for medium-scale production on marginal lands to serve this niche market is emerging; however, novel raisins with outstanding physicochemical, functional and antioxidant characteristics could compete successfully to those recently introduced in the market (blueberry and cranberry).

\section{Acknowledgments}

This study was supported by the Mexican National Council for Science and Technology (CONACYT, CB2009/134193). Project: Estudios básicos sobre diversidad y potencial agroalimentario del membrillo cimarrón (Amelanchier denticulata (Kunth) Koch) en el centro.

\section{References}

[1] Núñez-Colín CA, Hernández-Martínez MA, Escobedo-López D, Ortega-Rodríguez C. Priority areas to collect germplasm of Malacomeles (Rosaceae) in Mexico based on diversity and species richness indices. Plant Genetic Resources. 2012;10:128-33.

[2] Cazares-Franco MC, Ramírez-Chimal C, Herrera-Hernández MG, Nuñez-Colín CA, Hernández-Martínez MA, Guzmán-Maldonado SH. Physicochemical, nutritional and health-related component characterization of the underutilized Mexican serviceberry fruit [Malacomeles denticulata (Kunth) G. N. Jones]. Fruits. 2014;69(1):47-60.

[3] Moreno JJ, Cerpa-Calderón F, Cohen SD, Fang Y, Qian M, Kennedy JA. Effect of postharvest dehydration on the composition of pinot noir grapes (Vitis vinifera L.) and wine. Food Chemistry. 2008;109:755-62.

[4] Meng J, Fang Y, Zhang A, Chen S, Xu T, Ren Z, et al. Phenolic content and antioxidant capacity of Chinese raisins produced in Xinjiang Province. Food Research International. 2011;44:2830-6.

[5] Cañellas J, Rossello C, Simal S, Soler L, Mulet A. Storage conditions affect quality of raisins. Journal of Food Science. 1993;58(49):805-9.

[6] Belessiotis V, Delyannis E. Solar drying. Solar Energy. 2010;85:1665-91.

[7] AOAC. 2000. Official methods, Association of Official Analytical Chemists: Arlington, 2000.

[8] Prosky L, Asp NG, Schweizer TF, Devries JW, Furda I. Determination of insoluble, soluble, and total dietary fiber in foods and food products. Journal-Association of Official Analytical Chemists. 1988;71(5):1017-23.

[9] Singleton VL, Orthofer R, Lamuela-Raventós RM. Analysis of total phenols and other oxidation substrates and antioxidants by means of the Folin-Ciocalteu reagent. Methods in Enzymology. 1999;299:152-78.

[10] Deshpande SS, Cheryan M, Salunkhe DK. 1986. Tannin analysis of food products. CRC Critical Reviews in Food Science and Nutrition. 1986;24:401-44. 
[11] Abdel-Aal ESM, Hucl PA. A rapid method for quantifying total anthocynins in blue aleurone and purple pericarp wheats. Cereal Chemistry. 1999;76(3):350-4.

[12] Ramamurthy MS, Maiti B, Thomas PY, Nair M. High performance liquid chromatography determination of phenolic acids in potato tubers (Solanum tuberosum) during wound healing. Journal of Agricultural and Food Chemistry. 1992:40:569-57.

[13] Re R, Pellegrini N, Proteggente A, Pannala A, Yang M, Rice-Evans CA. Antioxidant activity applying an improved ABTS radical cation decolorization assay. Free Radical Biology \& Medicine. 1999;26(9-10):1231-7.

[14] Ou B, Hampsh-Woodill M, Prior R. Development and validation of an improved oxygen radical absorbance capacity assay using fluorescein as a fluorescent probe. Journal of Agricultural and Food Chemistry. 2001;49:4619-26.

[15] Fang YL, Zhang A, Wang H, Zhang ZW, Chen SX, Luan LY. Health risk assessment of trace elements in Chinese raisins produced in Xinjiang province. Food Control. 2010;21:732-39.

[16] Christensen LP, Peacock WL. Harvesting and handling. In Christensen LP, editor. Raising production manual. Davis: UCANR Publications; 2000. pp. 193-206.

[17] Gonnet JF. Colour effects of co-pigmentation of anthocyanins revisited-2. A colorimetric look at the solutions of cyanin co-pigmented by rutin using the CIELAB scale. Food Chemistry. 1999;66:387-94.

[18] Karadeniz F, Durst R, Wrolstad R. Polyphenolic composition of raisins. Journal of Agricultural and Food Chemistry. 2000;48:5343-50.

[19] Ghrairi F, Lahouar L, Amira LA, Brahmi F, Ferchichi A, Achour L, Said S. Physicochemical composition of different varieties of raisins (Vitis vinifera L.) from Tunisia. Industrial Crop and Products. 2013;43:73-7.

[20] AlAskari G, Kahouadji A, Khedid K, Charof R, Mennane Z. 2012. Physicochemical and Microbiological Study of "Raisin", Local and Imported (Morocco). Middle-East Journal of Scientific Research. 2012;11(1):1-6.

[21] Christensen LP, Peacock WL. The raising drying process. Harvesting and handling. In Christensen LP, editor. Raising production manual. Davis: UCANR Publications; 2000. pp. 207-216.

[22] Christensen LP. Raisin quality. In Christensen LP, editor. Raising production manual. Davis: UCANR Publications; 2000. pp. $228-235$.

[23] Sabandis D, Tzia C, Papadakis S. Effect of different raisin juice preparations on selected properties of gluten-free bread. Food and Bioprocess Technology. 2008;1:374-83.

[24] Camire ME Dougherty, MP. Raisin dietary fiber composition and in vitro bile acid binding. Journal of Agricultural and Food Chemistry. 2003;51:834-37.

[25] Saura-Calixto F. Dietary fiber as a carrier of dietary antioxidants: An essential physiological function. Journal of Agricultural and Food Chemistry. 2011;59:43-9.

[26] Williamson G, Carughi A. Polyphenol content and health benefits of raisins. Nutritional Researcj. 2010;30(8):511-19.

[27] Anderson JJB, Allen J. Nutrition of macro elements and trace elements. In: Golberg I, editor. Functional foods: designer foods, pharmafood, nutraceutical. New York: Chapman and Hall; 1999. pp. 323-354.

[28] Breksa III AP, Takeoka GR, Hidalgo MB, Vilches A, Vasse J, Ramming DW. Antioxidant activity and phenolic content of 16 raisin grape (Vitis vinifera L.) cultivars and selections. Food Chemistry. 2010;121:740-45.

[29] Proteggente AR, Pannala AS, Paganga G, Van Buren L, Wagner E, Wiseman S, et al. The antioxidant activity of regularly consumed fruit and vegetables reflects their phenolic and vitamin C composition. Free Radical Research. 2002;36(2):217-23.

[30] Ehlenfeldt MK, Prior RL. Oxygen radical absorbance capacity (ORAC) and phenolic and anthocyanin concentrations in fruit and leaf tissues of highbush blueberry. Journal of Agricultural and Food Chemistry. 2001;49:2222-7.

[31] Corrales-Aguayo RD, Yahia EM, Carrillo-López A, González-Aguilar G. 2008. Correlation between some nutritional components and the total antioxidant capacity measured with six different assays in eight horticultural crops. Journal of Agricultural and Food Chemistry. 2008;56:10498-504.

[32] Chung K, Wong TY, Wei C, Huang Y. Lin Y. Tannins and human health: A review. CRC Critical Reviews in Food Science and Nutrition. 1998;38(6):421-64.

[33] Mazza G. Chemical composition of Saskatoon berries (Amalenchier ainifolia Nutt.). Journal of Food Science. 1982;47:1730-1.

[34] Rogiers SY, Knowles NR. Physical and chemical changes during growth, maturation, and ripening of Saskatoon (Amelanchier alnifolia) fruit. Canadian Journal of Botany. 1997;75:1215-25.

[35] Wolfram S, Raederstorff D, Preller M, Wang Y, Teixeira SR, Riegger C, Weber P. Epigallocatechin gallate supplementation alleviates diabetes in rodents. Journal of Nutrition. 2006;36(10):2512-8.

[36] Waltner-Law ME, Wang XL, Law BK, Hall RK, Nawano M, Granner DK. Epigallocatechin gallate, a constituent of green tea, represses hepatic glucose production. The Journal of Biological Chemistry. 2002;277(38):34933-40.

[37] Rice-Evans CA, Miller NJ, Paganga G. Structure-antioxidant activity relationships of flavonoids and phenolic acids. Free Radical Biology \& Medicine. 1996;20(7):933-56. 